Vol. 4, No. 4, 2019

\title{
IMPROVEMENT OF ENVIRONMENTAL SAFETY OF AGRICULTURAL SYSTEMS AS A RESULT OF ENCAPSULATED MINERAL FERTILIZERS IMPLEMENTATION
}

\author{
Serhiy Synelnikov, Khrystyna Soloviy, Myroslav Malovanyy, \\ Ivan Tymchuk, Oleh Nahurskyy \\ Lviv Polytechnic National University, \\ Institute of Sustainable Development, \\ Department of Ecology and Sustainable Environmental Management, \\ 12, S. Bandery Str., Lviv, 79013, Ukraine \\ Vk.pozh@gmail.com_christina.gf@gmail.com, \\ i.s.tymchuk@gmail.com,o_nagurskyy@ukr.net
}

https://doi.org/10.23939/ep2019.04.222

Received: 04.11.2019

(C) Synelnikov S., Soloviy K., Malovanyy M., Tymchuk I., Nahurskyy O., 2019

\begin{abstract}
The impact of mineral fertilizers on an agricultural system has been analyzed. It has been shown that encapsulated fertilizers of prolonged action are the effective type of fertilizers that enable to achieve rich harvests and simultaneously consistently reduce the load on the agricultural system. Balance calculations on evaluating the agricultural system contamination level in case of implementing granulated and encapsulated fertilizers have been carried out. It has been shown that in case of using encapsulated fertilizers instead of granulated fertilizers, the environmental contamination caused by excessive nutrition elements of mineral fertilizers indigested by the plants decreases almost fourfold. Pilot experiments on using such cultures as potato, soy, and maize have proven that the effectiveness of using encapsulated fertilizers in comparison with granulated fertilizers under condition of less expenses of mineral fertilizer is $30-50 \%$ higher.
\end{abstract}

Key words: encapsulated mineral fertilizers, agricultural system, environmental contamination, prolonged action.

\section{Introduction}

As a result of anthropogenic impact on the environmental ecosystems, Ukrainian environmental degradation leads to the environmental sustainability loss and makes sustainable development of the country impossible [1, 2]. Global changes in the environment create a threat to the life and health of Ukrainian citizens.
This is why, if we accept the health of the population as an integral indicator of the negative anthropogenic impact on the environment, then objective statistical medical data indicate a growing influence of environmental factors on the physical potential of our society [3].

Environmental degradation is mainly caused by outdated production technologies, outdated and worn-out equipment, high energy and material consumption level that two or three times exceeds relevant indicators of the developed countries; high level of concentration of industrial objects; unfavourable structure of industrial production with high concentration of environmentally hazardous productions; absence of relevant nature protection systems (treatment plants, circulating water supply systems etc), low exploitation level of available nature protection objects; absence of proper legal and economic mechanisms that would stimulate development of environmentally safe technologies and nature protection systems; absence of proper environmental protection control $[4,5]$. The aforementioned factors, as well as a low level of environmental awareness of the society, have led to excessive pollution of surface and underground waters, air, and land, and accumulation of a very large amount of harmful, including highly toxic production waste $[6,7]$.

One of the components that might negatively affect the agricultural system is mineral fertilizers. Given this, in environmental literature, main theoretic provisions are shaped on the environmental and economic efficiency of using mineral fertilizers and chemical agents for plant 
protection in the agriculture that are the main factors of soil contamination with chemical compounds, including contamination with heavy metals.

The notion "effect from mineral fertilizers on agricultural system" is traditionally interpreted as dualistic that comprises the improvement of qualitative indicators and agricultural productivity on the one hand and on the other hand, environmental protection from the use of agrochemicals. In general, this notion is specific and has not any unambiguous interpretation that would reveal a full understanding of the essence and content. However, the problem of the impact of mineral fertilizers on the agricultural system is quite complicated and versatile. It appeared in the last decades of human development. Scientific explanation of the notion «effect from mineral fertilizers on agricultural system» is both theoretically and practically important, because it is connected with the permissible level of anthropogenic impact on land and natural resources on the one hand and the role of a particular factor of this influence on the other.

In order to minimize the negative impact of mineral fertilizers on the agroecosystem, it is advisable, in our opinion, to investigate environmentally hazardous processes in the conditions of intensive use of mineral fertilizers; substantiate the main directions of management activities to minimize the negative impact of fertilizers; develop directions for improving the economic mechanism regulating the application of mineral fertilizers; develop and implement new fertilizer technologies and new fertilizer forms, which on the one hand would make it possible to achieve high yields and quality of agricultural products, and on the other - to minimize the negative impact of residual fertilizers on the agroecosystem.

The negative impact of mineral fertilizers on the agroecosystem can be divided into global, covering the entire planet; national that concerns individual states; regional that is relevant to certain regions of these states; and local, affecting separate some areas. In general, agricultural production has turned into a complex set of anthropogenic impacts on the agroecosystem.

We think that new perspective fertilizers are the fertilizers of prolonged action, which is achieved by encapsulating traditional granulated fertilizers with a water-permeable shell (capsule).

The application of the shell (capsule) on the surface of the fertilizer granules slows down the process of transition of the nutrients into the soil environment, which increases the rate of their absorption by plants. Accordingly, the required dose of fertilizers, the frequency of their application, the loss of fertilizers not utilized by the plants (leading to its contamination), etc., are reduced.
Despite a large number of the developed filmforming materials, the production of encapsulated mineral fertilizers is small and refers mostly to nitrogen fertilizers. Globally its production reaches only $0.4-0.5 \%$. Such low production of encapsulated mineral fertilizers is due to a significant increase in their cost, compared to conventional granulated fertilizers. A promising way to increase the availability of encapsulated mineral fertilizers for their implementation in mass agriculture is the use of polymeric wastes and the improvement of coating technology. Industrial polymeric wastes, as a rule, are recycled directly at the enterprises. At the same time, in Ukraine, household polymeric wastes are being heavily landfilled into municipal solid wastes.

The household polymeric wastes include articles made of the following materials:

- Polyethylene - bags, bottles, stretch film for food packaging;

- Polystyrene - disposable tableware, packaging materials;

- Polyvinyl chloride - stretch film for food packaging, shower curtains, raincoats, bottles, visors;

- Polypropylene - bottles, drinking straws, disposable tableware, food containers;

- Polyethylene terephthalate - bottles for carbonated beverages, packages.

Polymeric materials that are used as the basis of filmforming compositions have to meet two basic criteria:

- provide relevant intensity of mineral nutrition components release;

- be environmentally safe - after the release of fertilizer components, shell material should be neutralized in a certain way to avoid soil contamination by polymers.

These conditions could be met by polyethyl terephthalate (PET), as long as its solubility is provided, which plays a crucial role in the process of creating a film-forming composition and coating the mineral fertilizer granules. For PET, the system of separate collection (used PET bottles) and recycling (secondary raw materials for production of fiber, PET bottles, sheets for thermoforming, strapping tape, etc.) is widely developed in Ukraine and other countries of the world.

We have investigated the possibility of PET modification by implementing an alcoholysis reaction using diethylene glycol as a reagent [8]. The result is a solubility of modified PET in ethyl acetate, sufficient for implementation of the technological process of encapsulation in the fluidized bed apparatus. For the studies, PET wastes were used in the form of flakes that had undergone primary processing at a specialized plant, and diethylene glycol (DEG) in a molar ratio of PET: DEG 1: 0.5, which were loaded into a sealed reactor. The 
content of the reactor was heated to a temperature of 493K. Two hours after reaching the required temperature, the vacuum pump was switched on, and ethylene glycol was distilled from the reactor at a residual pressure of $20 \mathrm{kPa}$. The total duration of the process was 3.5 hours. As a result of the interaction, ethylene glycol is displaced by diethylene with obtaining a product soluble in ethyl acetate.

The feasibility of additional dusting of the obtained encapsulated fertilizer with natural sorbents to prevent sticking and aggregation has been studied. The use of capsuled fertilizers, obtained in this way, will significantly increase the economic and environmental performance of their use.

The purpose of the study was to determine a degree of environmental hazard reduction in case of using encapsulated mineral fertilizers and to establish environmental and agronomic efficiency of encapsulated mineral fertilizers by calculations and analysis of pilot experiments data.

\section{Experimental part}

Experiments have been carried out following the methodology [9] during 2018 on dark gray podzolized silt-loam soil of the plant protection laboratory of the Institute of Agriculture of the Carpathian region of the National Agrarian Academy of Sciences of Ukraine with studying the productivity of such cultures as potato, soy, maize.

The experiment included the following alternatives:

1. Control (without fertilizers);

2. Granulated fertilizer (nitroamophoska, N:P:K = $=16: 16: 16)-(\mathrm{GF})$;

3. Encapsulated fertilizer $(\mathrm{EF})$

\section{Results and discussion}

According to data [10], the average percentage value of useful use (as nutrients) of different fertilizer types in agroecosystems is:

- for nitrogen fertilizers - 50-60\%;

- for phosphorus fertilizers - 75-90\%;

- for potassium fertilizers $-60-80 \%$.

In order to establish the balance ratios of the use of different types of mineral fertilizers in agroecosystems, for the calculations, we accepted the losses which are half of the intervals given in [10], namely: nitrogen fertilizers $45 \%$, phosphorous $-17.5 \%$, potassium - $30 \%$. Nitrogen fertilizers are the most dangerous from the point of the negative impact on agroecosystems. From these fertilizers, nitrogen becomes part of the soil cycle.
Unused excess nitrogen fertilizers are distributed in the following way [10]:

$-50 \%$ is included in the soil organic matter;

$-50 \%$ is lost as intermediate compounds as a result of ammonification and denitrification processes.

Ammonification and denitrification processes result in the formation of gaseous compounds of nitrogen $\mathrm{NO}_{\mathrm{x}}$ and $\mathrm{NH}_{3}$. These compounds diffuse from the soil cover into the atmosphere. At the same time, a water-soluble $\mathrm{NO}_{3}$ ion is formed in the soil cover, which diffuses into the depth of this cover or is washed out with the groundwaters into the hydrosphere. Some of these compounds also enter the atmosphere in nitrogen oxide species (related to greenhouse gases) due to the implementation of denitrification processes. This is why considering the scale of the use of nitrogen fertilizers worldwide their contribution to climate change on the Earth is significant. According to data [11], the amount of nitrogen released into the atmosphere is $92 \times 10^{6} 106$ tons per year, which is equivalent to $60 \%$ of biologically bound nitrogen. Based on this, in terms of environmental protection, the most promising is the granulation of nitrogen fertilizers, which significantly reduces the degree of their decomposition as well as the pollution of the environment. If we consider complex fertilizers (all studies have been conducted using nitroamophoska as a basic fertilizer), a considerable degree of preservation of other nutrients (phosphorus and potassium) is achieved, because, in the decomposition of the nitrogen component, these components of the complex fertilizer are dispersed. And this, in turn, increases the risk of their leaching in the suspended or dissolved state in the hydrosphere.

The existing information from the researchers on the use of encapsulated fertilizers in agroecosystems does not give a definite answer as to the quantitative indicators of the reduction of environmental pollution resulting from the use of encapsulated mineral fertilizers. Researcher G. Yigal [12] estimated the reduction of environmental losses from encapsulated fertilizers compared to granulated $(25-50) \%$ in terms of the active substance.

We have carried out the balance calculations of the degree of introduction, digestion by plants, and losses in the agro-ecosystem of the nutrients from granulated and encapsulated mineral fertilizers. The results of the calculations are shown in Fig. 1.

As can be seen from the calculations, in case of the use of encapsulated fertilizers instead of granulated fertilizers, the environmental pollution by the residual fertilizers undigested by plants is reduced almost fourfold. Pilot studies have shown that the performance of encapsulated fertilizers is 30-50\% higher compared to granulated ones with lower consumption of mineral fertilizers. 


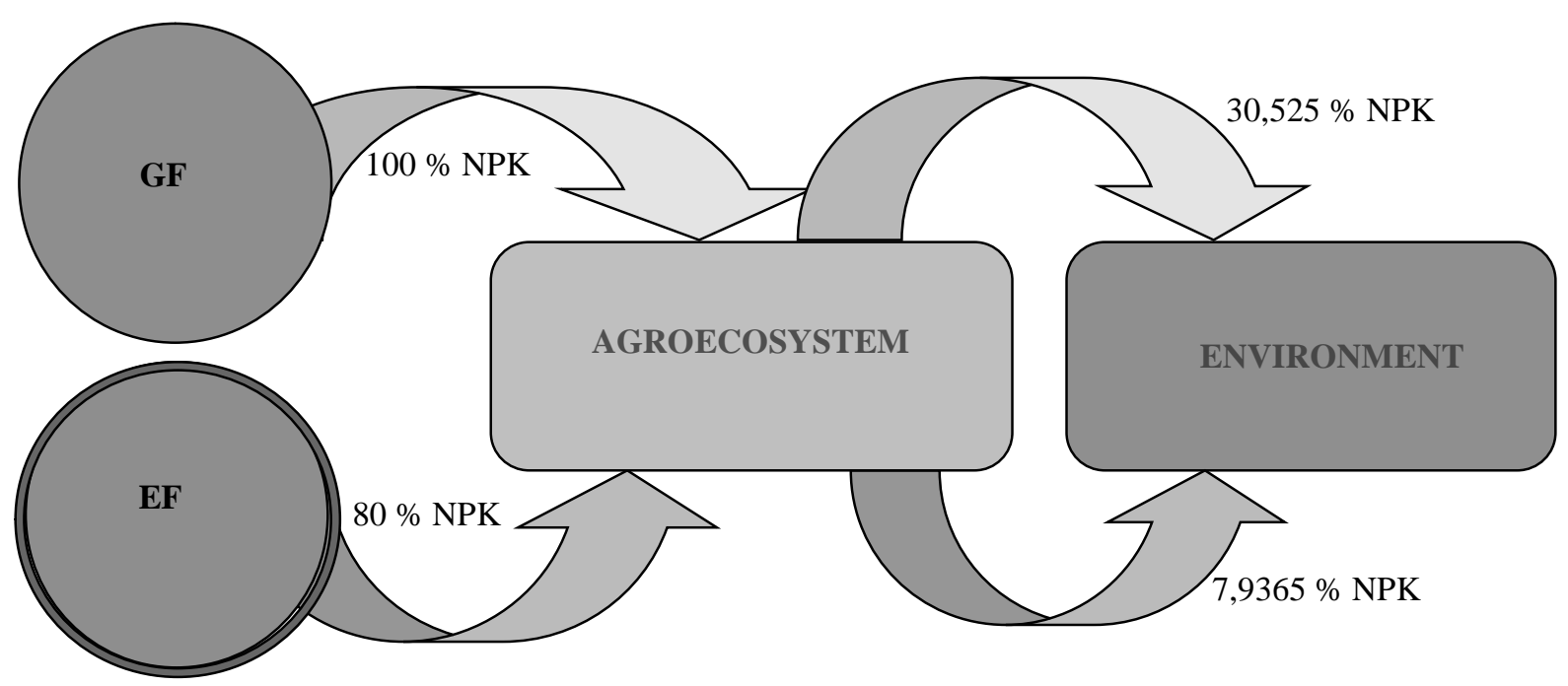

Fig. 1. Balance scheme of the impact of different types of fertilizers on the environment

For field studies on the effect of fertilizer type on potato productivity, the Shchedryk species have been used. The time of the vegetation period (from planting potatoes to dying of the bud) was 103 days. The potatoes of this species are rounded, yellow with white flesh. The flowers are white. The weight of the fruit of marketable potatoes is $100-110 \mathrm{~g}$. The potato of this species is suitable for processing into a number of products. The quality and taste characteristics of the species are good and are rated 4.1 points. The Shchedryk potato species is characterized by high drought resistance. For each type of fertilizer, the application rate was $0.8 \mathrm{t} / \mathrm{ha}$.

The area of each experimental plot was $25 \mathrm{~m}^{2}$. Threefold repetition has been applied in the studies. The potato planting density was 50 thousand bushes per 1 ha. The vegetation period of potatoes in the experimental plots lasted from 22.04.2018 to 27.08.2018.

The obtained results of the analysis of the effect of encapsulated fertilizers on the harvest and development of potatoes are shown in Table 1 .

Table 1

Impact of fertilizers on potato harvest (2018)

\begin{tabular}{|l|c|c|c|}
\hline \multirow{2}{*}{$\begin{array}{c}\text { Experimental } \\
\text { alternative }\end{array}$} & \multirow{2}{*}{$\begin{array}{c}\text { Harvest, } \\
\mathrm{t} / \mathrm{ha}\end{array}$} & \multicolumn{2}{|c|}{ Harvest growth } \\
\cline { 3 - 4 } $\begin{array}{l}\text { 1. Control (without } \\
\text { fertilizers) }\end{array}$ & 48.6 & & $\%$ \\
\hline 2. GF & & & \\
\hline 3. EF & 57.8 & 9.1 & 18.8 \\
\hline
\end{tabular}

Harvest growth in the alternative with application of granulated fertilizers averaged $9.1 \mathrm{t} / \mathrm{ha}$, when in the alternative with capsulated fertilizers it averaged $13.2 \mathrm{t} / \mathrm{ha}$. Higher harvest results in case of applying encapsulated fertilizers are ensured by the uniform prolonged release of plant nutrients. As the rainfall in the first months of the vegetation period was sufficient, it caused the nutrients to be almost completely separated from the fertilizers, but the encapsulated fertilizer was able to provide a more timely and long-term release of the basic nutrients for optimum root development. Therefore, according to the results of the research, the most suitable option for providing the Shchedryk species of potatoes with nutrients under the meteorological conditions of the 2018 vegetation period is the use of mineral fertilizers encapsulated with PET.

For field studies on the effectiveness of the use of encapsulated fertilizers for soy cultivation, soy of Ivanka species has been selected. Table 2 shows the dynamics of harvest change of Ivanka species soy and the total weight of 100 seeds, depending on the type of the used fertilizers.

Table 2

\section{Impact of different fertilizer types on the harvest of Ivanka soybean}

\begin{tabular}{|l|c|c|c|c|}
\hline \multirow{2}{*}{ Alternative } & $\begin{array}{c}\text { Harvest, } \\
\text { t/ha }\end{array}$ & \multicolumn{2}{|c|}{$\begin{array}{c}\text { Harvest } \\
\text { growth for } \\
\text { control }\end{array}$} & $\begin{array}{c}\text { Weight of } \\
1000 \text { seeds, } g\end{array}$ \\
\cline { 3 - 4 } & t/ha & $\%$ & \\
\hline 1. Control & 1.8 & & & 140.83 \\
\hline 2. GF & 2.0 & 0.2 & 9.6 & 157.36 \\
\hline $3 . \mathrm{EF}$ & 2.5 & 0.7 & 37.3 & 160.18 \\
\hline
\end{tabular}

The results of the analysis of the performed research show that under the meteorological conditions of 2018, during the vegetation period of Ivanka soybean, the use of encapsulated fertilizer allowed to obtain better results compared to simple granulated fertilizer. A characteristic feature of soy is its ability to self-supply with the nitrogen necessary for plant development. A prerequisite for this is the development of tuber bacteria. And it is the introduction of encapsulated fertilizers that has a positive effect on the development of potatoes for the following reasons:

- a prolonged release of phosphorus and potassium component from the fertilizer capsule, which are stably nourishing plants for a considerable time, allows to ensure stable development and growth of potatoes; 
- when granulated fertilizers are used, the release of high nitrogen concentrations into the soil medium inhibits the growth and development of the bubbles (which is absent when encapsulated fertilizers are used). For encapsulated fertilizers, a small stable concentration of nitrogen compounds released from the capsule into the soil medium contributes to the stable growth and development of nitrogen fixers.

Delitop corn hybrid has been used for field research. In the research, the seeding rate of 80,000 seeds per ha has been used with $70 \mathrm{~cm}$ of row spacing. The rate of application of the investigated fertilizer types was $0.2 \mathrm{t} / \mathrm{ha}$. Threefold repetition has been investigated, in each case the area of the accounting plot was $25 \mathrm{~m}^{2}$. The technology of maize cultivation accepted for the conditions of the Western Forest-Steppe of Ukraine has been adopted. Phenological observations on the development and growth of Delitop hybrid maize have been performed during the vegetation period. Maize harvest has been accounted for in separate sections from each application of different fertilizer types.

The vegetation period lasted from May 01 to October 19, 2018.

The general view of Delitop hybrid maize crops in the flowering phase presented in Fig. 2 makes it possible to conclude that there is a clear visual difference in the quality of crops for different fertilizer types used.

Based on the analysis of the results of the studies, it has been revealed that the type of fertilizers used in the research has a significant impact on the onset and duration of phenological phases in Delitop hybrid maize.

The results of the observations are shown in Table 3.

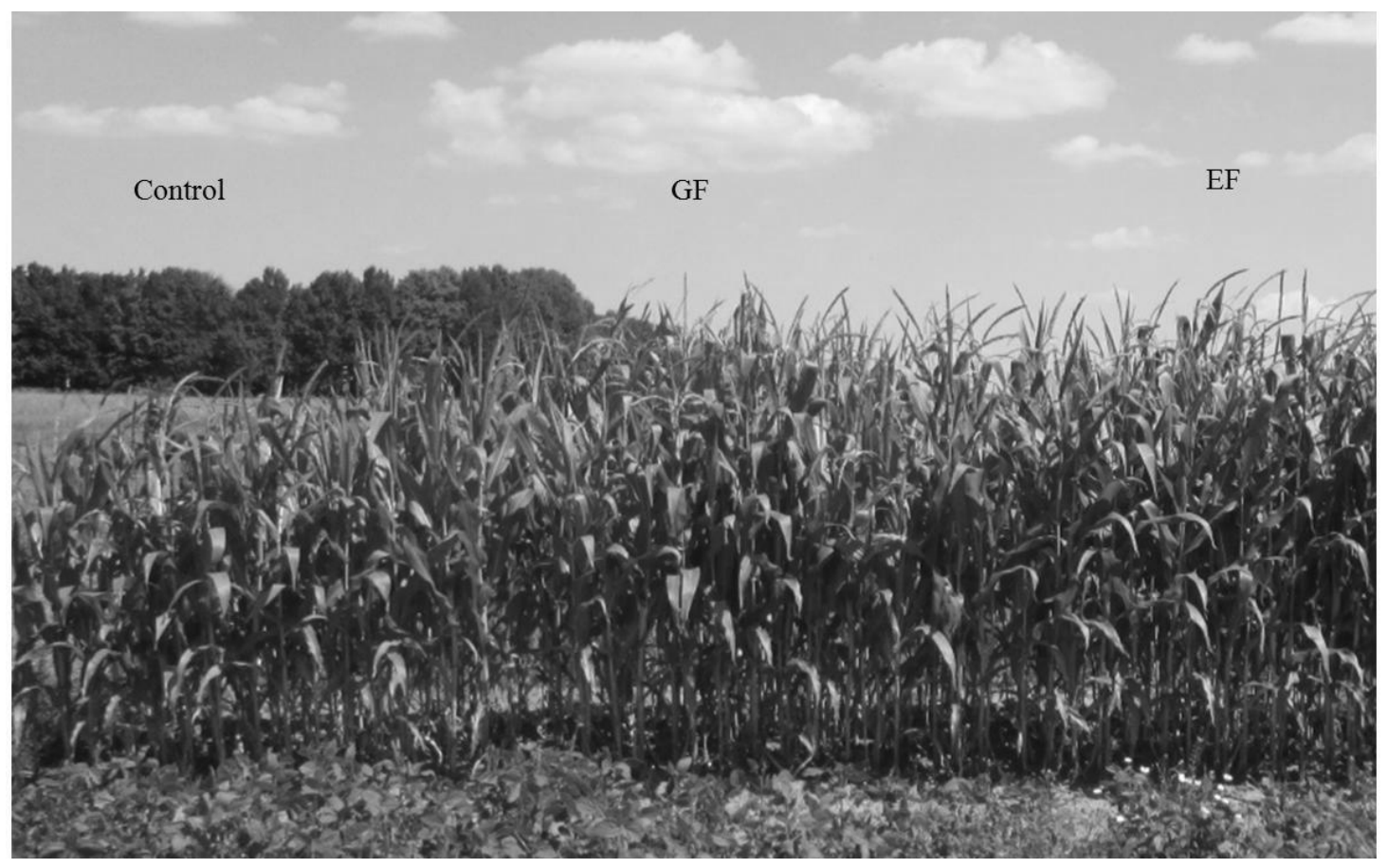

Fig. 2. General view of maize crops with various use of different mineral fertilizer types (2018)

Impact of the application of different types of fertilizers on maize phenophases

\begin{tabular}{|l|c|c|c|}
\hline \multirow{2}{*}{ Phenological phase } & \multicolumn{3}{|c|}{ Experimental alternative } \\
\cline { 2 - 4 } & Control without fertilizers & GF & EF \\
\hline Sowing & 01.05 & 01.05 & 01.05 \\
\hline Sprouting & 07.05 & 07.05 & 07.05 \\
\hline Ejection of panicle & 19.07 & 21.07 & 23.07 \\
\hline The beginning of panicle flowering & 20.07 & 22.07 & 24.07 \\
\hline Full panicle flowering & 23.07 & 26.07 & 27.07 \\
\hline The beginning of cobs flowering & 23.07 & 24.07 & 25.07 \\
\hline Full cobs flowering & 26.07 & 27.07 & 29.07 \\
\hline Milk ripeness & 09.08 & 11.08 & 12.08 \\
\hline Milk-wax ripeness & 20.08 & 22.08 & 25.08 \\
\hline Wax ripeness & 06.09 & 09.09 & 14.09 \\
\hline Full ripeness & 10.10 & 14.10 & 19.10 \\
\hline Harvesting & 19.10 & 19.10 & 19.10 \\
\hline
\end{tabular}


The best effect on the initial stages of development was caused by granulated fertilizer. Due to the release of the maximum number of nutrients at the «second - eighth leaf» stage, which corresponds to the most critical phases of maize development, the plant is provided with an adequate amount of nutrients, which facilitates strong potential for maize development. But since vegetation period of maize is quite long, the plants actively digest the nutrients until the cobs are fully ripe. That is why the use of encapsulated fertilizer has allowed providing high maize harvest as a whole.

The results of the analysis of the experimental studies on the effect of different fertilizer types on the harvest of Delitop hybrid maize, as well as on the average weight of 100 seeds are shown in Table. 4.

Table 4

\section{Impact of different fertilizer types on hybrid Delitop maize harvest}

\begin{tabular}{|l|c|c|c|c|}
\hline \multirow{2}{*}{$\begin{array}{c}\text { Experimental } \\
\text { alternative }\end{array}$} & \multirow{2}{*}{$\begin{array}{c}\text { Harvest, } \\
\text { t/ha }\end{array}$} & \multicolumn{2}{|c|}{$\begin{array}{c}\text { Harvest } \\
\text { growth }\end{array}$} & \multirow{2}{*}{$\begin{array}{c}\text { Weight of } \\
\text { lon seeds, g }\end{array}$} \\
\cline { 3 - 4 } & t/ha & $\%$ & \\
\hline $\begin{array}{l}\text { 1. Control } \\
\text { (without } \\
\text { fertilizers) }\end{array}$ & 8.3 & & & 301.8 \\
\hline 2. GF & 9.2 & 0.9 & 10.9 & 324.7 \\
\hline 3. EF & 9.5 & 1.2 & 14.8 & 329.9 \\
\hline
\end{tabular}

As a result of the data analysis presented in Table 4, we can conclude that of all the tested alternatives the encapsulated fertilizer appeared to be the best, which provided the harvest growth of $1.2 \mathrm{t} /$ ha compared to the control (granulated fertilizer provided the harvest growth of $0.9 \mathrm{t} / \mathrm{ha})$.

To evaluate the environmental performance of fertilizers, we use an indicator that characterizes the reduction of fertilizer losses compared to traditional (granulated). To evaluate agronomic performance, we introduce an indicator such as the efficiency of the fertilizer, the calculation of which will be performed according to the formula:

$$
C_{e f}=\frac{H-H_{b}}{G_{a c}},
$$

where $C_{e f}$ is the efficiency coefficient from using fertilizer, harvest tons/tons of active substance; $\mathrm{H}_{b}$ is harvest in the basic alternative (control without any application of fertilizers), t/ha; $\mathrm{H}$ is harvest under condition of applying certain fertilizer type, t/ha; $G_{\partial . p .}$ is the amount of active compound applied from a certain fertilizer type, $t$.

The fertilizer efficiency coefficient is essentially a characteristic of the fertilizer active substance efficiency - the amount of active substance expended per unit of the harvest. The assessment does not take into account the improvement in the quality of the harvest, which was recorded for all the harvests under study.

The results of the evaluation of the environmental and agronomic efficiency of the use of encapsulated mineral fertilizers are shown in Table 5.

Table 5

\section{Assessment of environmental and agronomic efficiency of the tested fertilizers}

\begin{tabular}{|c|l|c|c|c|}
\hline \multirow{2}{*}{ № } & Cultures & $\begin{array}{c}\text { Reduction of losses } \\
\text { of nutrients in the } \\
\text { agroecosystem with } \\
\text { EF compared to } \\
\text { GF,\% / ha }\end{array}$ & \multicolumn{2}{|c|}{$\begin{array}{c}C_{e f} \text {, tons of } \\
\text { harvest/tons of } \\
\text { active compound }\end{array}$} \\
\cline { 4 - 5 } & & 74 & $\mathrm{GF}$ & $\mathrm{EF}$ \\
\hline 3 & Potato & 47.5 & 11.5 & 20.8 \\
\hline 4 & Maize & 47.5 & 4.5 & 4.4 \\
\hline
\end{tabular}

According to the results shown in Table 5, in case of potato cultivation and the use of encapsulated PET mineral fertilizers for this purpose, the environmental contamination from the nutrients indigested by plants (eco-efficiency of EF use) is reduced by $74 \%$ compared to the use of granulated fertilizers. At the same time, the agronomic efficiency of the use of encapsulated mineral fertilizers is increasing significantly. The application of 1 ton of the active ingredient of fertilizers in a capsule type increases the potato harvest up to 20.8 tons, whereas for granulated fertilizers it will be 11.5 tons.

In the case of soy and maize cultivation and the use of encapsulated PET mineral fertilizers, environmental pollution from the nutrients indigested by plants (ecoefficiency of EF) is reduced by $47.5 \%$ compared to the use of granular fertilizers. The agronomic efficiency of these crops in the case of encapsulated fertilizers is obvious:

- The application of 1 ton of the active ingredient of encapsulated fertilizers increases the soy harvest to 4.4 tons (for granulated fertilizers the harvest increases to 1 ton).

- The application of 1 ton of the active ingredient of encapsulated fertilizers increases maize harvest to 7.5 tons (for granulated fertilizers this figure is 4.5 tons).

It is important to take into account that in the case of using encapsulated fertilizers, the need for the active substance significantly reduces up to $20 \%$. If to assume that encapsulated fertilizers would facilitate to substitute all the fertilizers used in Ukraine (which is usually only possible in the long term), then it would be possible to reduce the production of these fertilizers by $20 \%$, reducing the use of natural resources, as well as the scale of production and accordingly the scale of environmental pollution from this production.

Thus, for all the cultures under the study, the coefficient of fertilizer efficiency is much higher for the encapsulated fertilizers compared to the granulated ones 
(maximum - more than fourfold). With a smaller amount of the active ingredient, the harvest on the areas where the fertilizer is encapsulated is much higher. This confirms the high agronomic efficiency of the use of encapsulated mineral fertilizers in the agricultural agro-technology.

\section{Conclusions}

The analysis of the results of the field experiments shows that in case of application of encapsulated mineral fertilizers in the agro-ecosystems of such crops as potatoes, soybeans, and maize, digestion of the fertilizer nutrients by plants increases on average by $4.5 \%$. Atmospheric and hydrosphere losses in the case of using encapsulated fertilizers decrease compared to granulated fertilizers from $47 \%$ to $74 \%$.

The use of prolonged-action encapsulated mineral fertilizers has shown a significantly higher environmental and agronomic efficiency compared to granulated fertilizers.

- In the case of potato cultivation, the environmental efficiency of the use of encapsulated PET mineral fertilizers increases by $74 \%$ compared to granulated fertilizers. The application of 1 ton of the active substance of fertilizers in a capsule type causes potato harvest to increase to 20.8 tons, while for granulated fertilizers it is 11.5 tons.

- in the case of soybean cultivation, the environmental efficiency of the use of encapsulated PET mineral fertilizers increases by $47.5 \%$ compared to granulated fertilizers. The application of 1 ton of the active substance of fertilizers in a capsule form causes the soy harvest to increase to 4.4 tons whereas for granulated fertilizers it is 1 ton.

- in the case of maize cultivation, the environmental efficiency of the use of encapsulated PET mineral fertilizers increases by $47.5 \%$ compared to granulated fertilizers. The application of 1 ton of the active substance of fertilizers in a capsule form causes maize harvest to increase to 7.5 tons whereas for granulated fertilizers it is 4.5 tons.

The use of encapsulated fertilizers reduces the need for the active substance by $20 \%$. The introduction of encapsulated fertilizers would reduce the production of these fertilizers by $20 \%$ and, accordingly, the use of natural resources, as well as the scale of production and, accordingly, reduce the environmental pollution from this production.

\section{References}

[1] Markin B. M., Naumova L. H. Populyarnyy ekolohicheskiy slovar. Moskva, 1999, 304 s.

[2] Vstup do medichnoi heolohii. T.1 / Rudko H. I. ta in.; za red. H. I. Rudka. Kyiv, 2010. 736 s.

[3] ZvinackovskyyYa. M, Berdnik O. V. Faktory riska I zdorove naseleniya, prozhivayushcheho $\mathrm{v}$ raslichnykh usloviyakh okruzhayushchey sredi. Dovkilla ta zdorovya. 2000. No. 1. S. 8-11.

[4] Karachka V. Zmishani kompleksni dobriva: stan, problem I perspektyvy. AhroPerspektyva. 2006. No. 2. S. $56-58$.

[5] Vasilenko S. L. Ekolohicheskaya bezopasnost vodosnabzheniya. Kharkiv, 2006. $320 \mathrm{~s}$.

[6] Sumatokhina I. M., Duk N. M., Shevchenko O. A. Hlobalna ekolohichna kriza. Scenarii maybutnoho lyudstva. Ekolohiya dovkillya ta bezpeka zhittediyalnosti. 2008. No. 1. S. 24-26.

[7] Hyrenok F. I. Ekolohiya. Zyvilizaciya. Noosfera. Moskva, 1987. $182 \mathrm{s.}$

[8] Moroz O. I., Malovanyy M. S., Sinelnikov S. D ta insh. Rozkritta problem zastosuvannya innovaciynykh typiv prolonhovanoi dii $\mathrm{v}$ navchalnomu kursi "Ahroekolohiya". Tezy konf. "Upravlinnya yakistyu pidhotovky fakhivciv", Odesa, 26-27 bereznya 2019 r. s. $114-116$.

[9] Dospekhov B. A. Metodika polevoho opita [5-e izd., dop. I pererab.] / B.A. Dospekhov. M.: Ahropromuzdat, 1985. $351 \mathrm{~s}$.

[10] Horodniy M. M., Shykula M. K. Ahroekolohiya. Kyiv, 1993. $347 \mathrm{~s}$.

[11] Mengel K. Impacts of intensiveplant nutrient management on cropproduction and environment. K.Mengel Congress of Soil Science: Materials 14-th Inttrnational Congress 12-18 August 1990. Stuttgart, 1990. P. 89-93.

[12] Yigal G., Zukerman How to boost nitrogen use efficiency. International journal of fertility and menopausal studies. 2004. No. 400. P. 147-151. 